Tropical Journal of Pharmaceutical Research March 2017; 16 (3): 627-632

ISSN: $1596-5996$ (print); 1596-9827 (electronic)

(C) Pharmacotherapy Group, Faculty of Pharmacy, University of Benin, Benin City, 300001 Nigeria.

All rights reserved.

Available online at http://www.tjpr.org

Original Research Article

http://dx.doi.org/10.4314/tjpr.v16i3.18

\title{
Chemical composition of the essential oil of whole plant of Elsholtizia dense Benth and its anti-tumor effect on human hepatoma cells
}

\author{
Wen-yuan Xin, Jiao Li, Dan-wei Ma*, Yanan Wang, Qiurong Ren and Jia-jia Li \\ College of Life Science, Sichuan Normal University, Chengdu 610101, PR China
}

*For correspondence: Email: danwei10ma@163.com

Received: 17 October 2016

Revised accepted: 14 February 2017

\begin{abstract}
Purpose: To determine the chemical components of the essential oil of Elsholtizia dense in Sichuan Province and evaluate the effect of the oil on human hepatoma cells (SMMC-7721) in vitro.

Methods: The essential oil was extracted using the modified steam-distillation extraction method, and its chemical components were determined by gas chromatography-mass spectrometry (GC-MS). The effect of the essential oil on proliferation of SMMC-7721 cells was studied by 3-(4,5-dimethyl-2thiazolyl)-2,5-diphenyl-2-H-tetrazolium bromide (MTT) assay, with L02 and HeLa cells serving as control groups.

Results: GC-MS results show that the essential oil of E. dense contains 40 components. Thirty seven components were identified and accounted for $98.39 \%$ of the essential oil. The two main components were rosefuran epoxide $(53.12 \%)$ and 2-ethyl imidazole $(29.8 \%)$. The oil significantly inhibited cell proliferation in a concentration- and time-dependent manner $(p<0.05)$. SMMC-7721 cells were more inhibited than LO2 and HeLa cells by the oil, with half maximal inhibitory concentration (IC $\left.\mathrm{C}_{50}\right)$ values of 26.23 and $25.46 \mu \mathrm{g} / \mathrm{mL}$ after 8-h and 24-h treatments, respectively.

Conclusion: Out of the 40 chemical components of the essential oil of $E$. dense, rosefuran epoxide and 2-ethyl imidazole were the most abundant. The oil has a significant anti-tumor effect on SMMC-7721 cells, and thus has a potential to be developed as an anti-liver cancer drug.
\end{abstract}

Keywords: Medicinal herb, Elsholtizia dense Benth, Essential oil, Rosefuran epoxide, 2-Ethyl imidazole, Anti-tumor activity

Tropical Journal of Pharmaceutical Research is indexed by Science Citation Index (SciSearch), Scopus, International Pharmaceutical Abstract, Chemical Abstracts, Embase, Index Copernicus, EBSCO, African Index Medicus, JournalSeek, Journal Citation Reports/Science Edition, Directory of Open Access Journals (DOAJ), African Journal Online, Bioline International, Open-J-Gate and Pharmacy Abstracts

\section{INTRODUCTION}

Elsholtizia dense Benth belonging to Labiatae, is found in the west of China, including Sichuan, Shanxi and Qinghai. E. dense is one of the sources of the Tibetan medicine, Qirou [1]. It has anti-inflammatory, anti-pruritic, myogenic, and hemostatic effects [2], and also could remove necrotic tissue and repel mosquito [3]. It has been traditionally applied to treat several diseases such as summer cold, scabies, syphilitic rhinitis, laryngitis, skin itching, furuncle carbuncle and stomach disease in China [2,3]. The main medicinal components of $E$. dense is its essential oil $[2,4-6]$. The essential oil of many plants has been reported to have an inhibitory effect on tumor cells [7-13]. However, the antitumor effect of the essential oil from $E$. dense in Sichuan Province has been seldom studied.

The chemical composition of the essential oil from $E$. dense has been reported in several studies [2,4-6]. However, the chemical composition of the essential oil differs in different 
regions where $E$. dense grows. The chemical components of the essential oil from $E$. dense in Sichuan Province have not been identified until now.

Therefore, the aim of this study was to identify the chemical components of the essential oil from $E$. dense in Sichuan Province and investigate its anti-tumor effect. In this study, the plant was collected from alpine meadow in Hongyuan County of Sichuan Province. The essential oil was isolated from the whole plant using the modified steam-distillation extraction method. The chemical components were identified using gas chromatography-mass spectrometer (GC-MS) analysis. The effect of the essential oil on the proliferation of normal human liver cells (L02), human hepatoma cells (SMMC7721) and human cervical carcinoma cells (HeLa) was studied by 3-(4,5-dimethyl-2thiazolyl)-2,5-diphenyl-2-H-tetrazolium bromide (MTT) assay.

\section{EXPERIMENTAL}

\section{Plant materials}

The plants of $E$. dense were collected from alpine meadow in Hongyuan County of Sichuan Province, and verified as $E$. dense by Professor Danwei Ma, Sichuan Normal University, China.

\section{Extraction of the essential oil from $E$. dense}

The whole plant of $E$. dense was dried in a shade. According to the modified steamdistillation extraction method previously described [4], the essential oil was obtained from $500 \mathrm{~g}$ of the dried whole plants boiled in a required amount of distilled water. Then the essential oil was dried with anhydrous sodium sulfate, and filtered through $0.22 \mu \mathrm{m}$ membrane. Finally it was stored in a sealed brown reagent bottle at $-20{ }^{\circ} \mathrm{C}$ for the experiments. Using this method the yield of the essential oil from $E$. dense was increased to $0.36 \%$.

\section{GC-MS analysis of the essential oil}

The chemical nature of the essential oil was analyzed by Gas Chromatography-Mass Spectrometer (GC-MS, Agilent 6890-5973, Agilent Technologies Inc. USA). Helium was used as carrier gas. The rate of Agilent DB-Wax capillary column $(60 \mathrm{~m} \times 0.25 \mathrm{~mm}, 0.25 \mu \mathrm{m}$ film thickness) was set at $1.0 \mathrm{~mL} / \mathrm{min}$. During the analysis period the temperature of $\mathrm{GC}$ oven was first set at $35^{\circ} \mathrm{C}$ for $10 \mathrm{~min}$ and then increased to $230{ }^{\circ} \mathrm{C}$ at the rate of $3{ }^{\circ} \mathrm{C} / \mathrm{min}$, and finally maintained at $230{ }^{\circ} \mathrm{C}$ for $10 \mathrm{~min}$. Split ratio was
5:1. The injector temperature was set at $230^{\circ} \mathrm{C}$. Mass spectra were recorded in the mass range of $\mathrm{m} / \mathrm{z} 35 \sim 450$ at $70 \mathrm{eV}$.

\section{Determination of chemical components of the essential oil}

The essential oil components was determined by comparison of their relative retention times to standard reference data from the National Institute of Standards and Technology (NIST) version 11 GC-MS libraries (USA). Quantification was determined by percentage peak area calculations using GC-FID.

\section{Cell culture}

SMMC-7721 cells, L02 cells and HeLa cells were grown as monolayers in RPMI-1640 medium supplemented with $10 \%$ fetal bovine serum and $1 \%$ antibiotics (100 U/mL penicillin and 100 $\mu \mathrm{g} / \mathrm{mL}$ streptomycin). Cells were maintained at $37{ }^{\circ} \mathrm{C}$ and $5 \%$ of $\mathrm{CO}_{2}$. The cells used in the experiments were in logarithmic growth phase.

\section{Determination of cell proliferation}

SMMC-7721 cells, L02 cells and HeLa cells were seeded at the density of $7 \sim 10 \times 10^{4} /$ well in a 96 well plate $(100 \mu \mathrm{L} /$ well $)$. After 12 hour incubation, the cells were adhered to the plate and treated with the essential oil from $E$. dense at 5 different concentrations, 10, 20, 30, 40, 50, $60 \mu \mathrm{g} / \mathrm{mL}$. Cells treated with $1 \%$ DMSO were negative control and cells treated with $80 \mu \mathrm{g} / \mathrm{mL}$ fluorouracil were positive control. After 8 or 24 hour treatment with the essential oil, $20 \mu \mathrm{L}$ of 5 $\mathrm{mg} / \mathrm{mL}$ MTT solution was added into the medium. After 4 hour incubation, the medium containing MTT was removed, and the remaining formazan crystals were dissolved by incubation with 150 $\mu \mathrm{L} /$ well DMSO on the oscillator for $10 \mathrm{~min}$. The absorbance $(A)$ value of each well was measured at the wavelength of $490 \mathrm{~nm}$ by microplate reader (MD/Spectra Max M2, USA). All experiments were performed 3 times. The cell proliferation inhibition rate was calculated as:

The cell proliferation inhibition rate $(\%)=\left[1-A_{\text {the }}\right.$ essential oil treated cells $/ A_{D M S O}$ control $] \times 100 \%$.

\section{Data statistics and analysis}

The data were analyzed using SPSS17.0 (SPSS Inc., USA). Significant differences were analyzed by Least-Significant Difference $(L S D)$ test. $P<$ 0.05 was considered statistically significant. All data are presented as mean \pm standard deviation (SD). The figures were drawn using Microsoft Excel 2003 (Microsoft, USA). 


\section{RESULTS}

\section{Composition of essential oil}

The chemical nature of the essential oil from $E$. dense was studied by GC-MS analysis. The chromatogram of the essential oil from $E$. dense (Figure 1) shows that the essential oil consisted of 40 chemical components. Thirty seven chemical components were identified (Table 1), and they accounted for $98.39 \%$ of the essential oil. Rosefuran epoxide accounted for $53.12 \%$ of the essential oil, followed by 2-ethyl imidazole $(29.8 \%)$, durenol $(2.87 \%)$, p-cymene $(2.11 \%)$, 1-cyanoacetyl-3,5-dimethylpyrazole (1.93\%) and 1,5,9,9-tetramethyl-1,4,7,-cycloundecatriene $(1.16 \%)$.

\section{Inhibitory activity of essential oil of $E$. dense}

Figure 2 shows a time- and concentrationdependent inhibitory effect of the essential oil on proliferation of 3 cell lines, which is similar to the positive control (treatment with $80 \mu \mathrm{\mu g} / \mathrm{mL}$ fluorouracil). The essential oil significantly inhibited proliferation of SMMC-7721 and HeLa cells in a concentration dependent manner during 8 hour treatment $(p<0.05$, Figure $2 A)$ and 24 hour treatment $(p<0.05$, Figure 2B). During 8 hour treatment the $\mathrm{IC}_{50}$ values for SMMC-7721, L02 and HeLa cells were 26.23, 36.64 and 44.46 $\mu \mathrm{g} / \mathrm{mL}$, respectively. During 24 hour treatment the $\mathrm{IC}_{50}$ values for SMMC-7721, LO2 and HeLa cells were $25.46,53.16$ and $68.37 \mu \mathrm{g} / \mathrm{mL}$, respectively. These results suggest that SMMC7721 cells are the most sensitive to the inhibitory effect of the essential oil among these three cell lines.

\section{DISCUSSION}

In this study, the essential oil from $E$. dense collected from alpine meadow in Hongyuan County of Sichuan Province consists of 40 chemical components, with 37 components identified. The essential oil from $E$. dense shares some common components with other species of Elsholtzia: thymol, 1,8-cineole, $\beta$ dehydroelsholizione, elsholtzia ketone, linalool, carvacrol and $p$-cymene [14], however it differs in the chemical composition from other species of Elsholtzia [15-17].

In this study the main components of the essential oil from $E$. dense were identified as rosefuran epoxide $(53.12 \%)$, 2-ethyl imidazole $(29.8 \%)$, durenol $(2.87 \%)$, p-cymene $(2.11 \%)$, 1-cyanoacetyl-3,5-dimethylpyrazole (1.93\%) and 1,5,9,9-tetramethyl-1,4,7,-cycloundecatriene $(1.16 \%)$.

The essential oil of E. dense in Sichuan Province also differs in the chemical composition from $E$. dense growing in other regions [3-5].

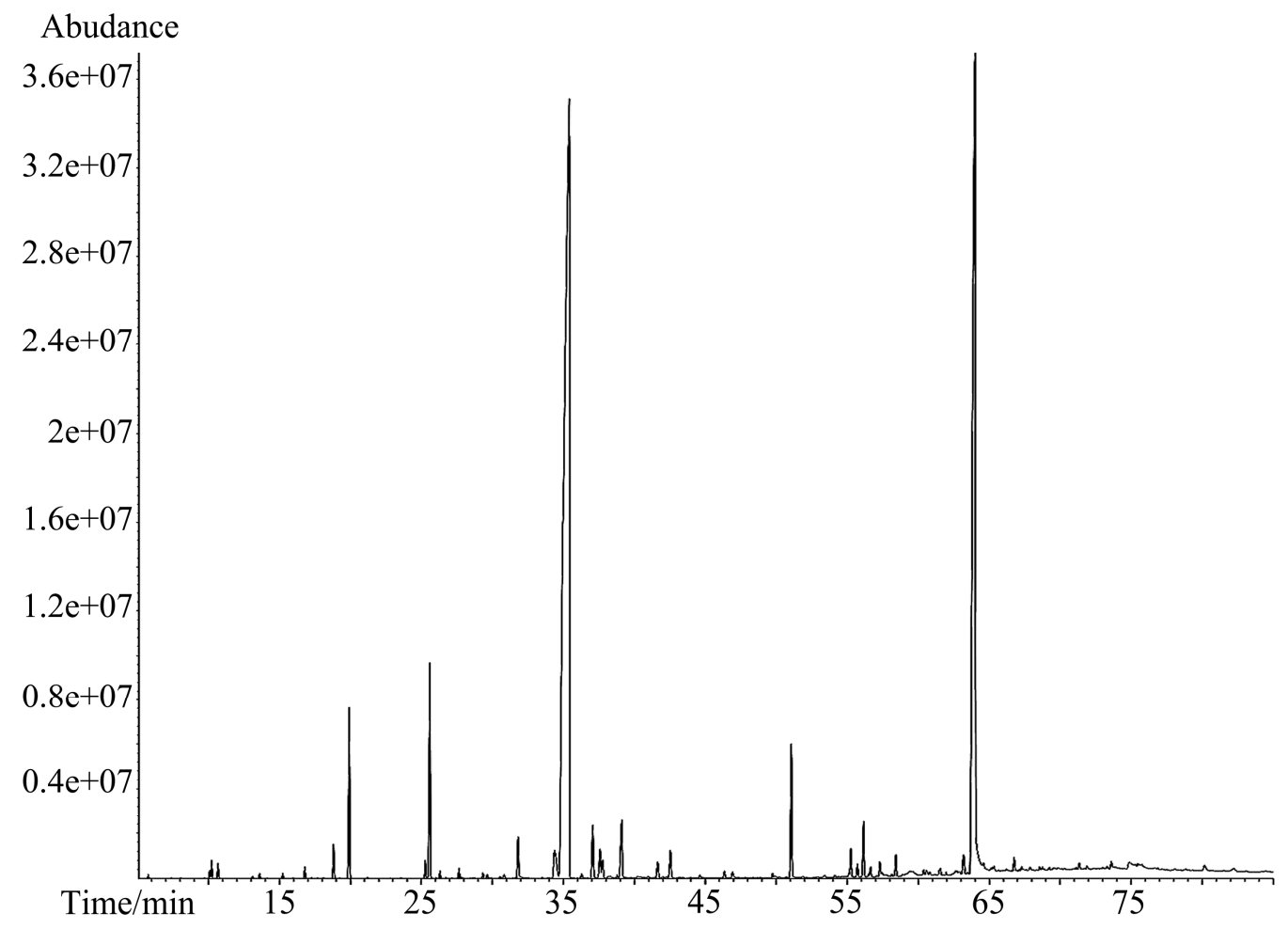

Figure 1: Chromatogram of the essential oil of $E$. dense 
Table 1: Chemical components of the essential oil of E. dense

\begin{tabular}{|c|c|c|c|c|}
\hline S/no. & Compound & $\begin{array}{l}\text { Retention time } \\
\text { (min) }\end{array}$ & $\begin{array}{l}\text { Relative content } \\
(\%)\end{array}$ & $\begin{array}{c}\text { Molecular } \\
\text { formula }\end{array}$ \\
\hline 1 & Acetone & 5.754 & 0.05 & \\
\hline 2 & $(1 \mathrm{R})-(+)-\alpha$-pinene & 10.095 & 0.09 & $\mathrm{C}_{10} \mathrm{H}_{16}$ \\
\hline 3 & 3-thujene & 10.223 & 0.21 & $\mathrm{C}_{10} \mathrm{H}_{16}$ \\
\hline 4 & 2-methyl-3-buten-2-ol, & 10.671 & 0.18 & $\mathrm{C}_{5} \mathrm{H}_{10} \mathrm{O}$ \\
\hline 5 & $\beta$-phellandrene & 13.605 & 0.06 & $\mathrm{C}_{10} \mathrm{H}_{16}$ \\
\hline 6 & $\beta$-myrcene & 15.233 & 0.06 & $\mathrm{C}_{10} \mathrm{H}_{16}$ \\
\hline 7 & $D$-limonene & 16.788 & 0.14 & $\mathrm{C}_{10} \mathrm{H}_{16}$ \\
\hline 8 & $\gamma$-terpinene & 18.816 & 0.40 & $\mathrm{C}_{10} \mathrm{H}_{16}$ \\
\hline 9 & o-cymene & 19.923 & 2.11 & $\mathrm{C}_{10} \mathrm{H}_{14}$ \\
\hline 10 & 3-octanol & 25.281 & 0.19 & $\mathrm{C}_{8} \mathrm{H}_{18} \mathrm{O}$ \\
\hline 11 & Durenol & 25.593 & 2.87 & $\mathrm{C}_{10} \mathrm{H}_{14} \mathrm{O}$ \\
\hline 12 & Perillen & 26.31 & 0.08 & $\mathrm{C}_{10} \mathrm{H}_{14} \mathrm{O}$ \\
\hline 13 & mushroom alcohol & 27.651 & 0.12 & $\mathrm{C}_{8} \mathrm{H}_{16} \mathrm{O}$ \\
\hline 14 & 5-methyl-2-furancarboxaldehyde & 29.342 & 0.07 & $\mathrm{C}_{6} \mathrm{H}_{6} \mathrm{O}_{2}$ \\
\hline 15 & $\begin{array}{l}\text { 3-isopropoxy-1,1,1,7,7,7-hexamethyl- } \\
\text { 3,5,5-tris(trimethylsiloxy)tetrasiloxane }\end{array}$ & 29.641 & 0.05 & $\mathrm{C}_{18} \mathrm{H}_{52} \mathrm{O}_{7} \mathrm{~S}_{7}$ \\
\hline $\begin{array}{l}16 \\
18\end{array}$ & $\begin{array}{l}(-)-\beta \text {-bourbonene } \\
\text { unidentified }\end{array}$ & $\begin{array}{c}30.83 \\
34.389\end{array}$ & $\begin{array}{l}0.08 \\
1.00\end{array}$ & $\mathrm{C}_{15} \mathrm{H}_{24}$ \\
\hline 19 & rosefuranepoxide & 35.405 & 53.12 & $\mathrm{C}_{10} \mathrm{H}_{14} \mathrm{O}_{2}$ \\
\hline $\begin{array}{l}20 \\
21 \\
22 \\
23\end{array}$ & $\begin{array}{l}\text { 1-ethyl-3-(1-methylethyl)- Benzene } \\
\text { 4-pyridazinamine } \\
\text { longifolene } \\
\text { acetophenone }\end{array}$ & $\begin{array}{l}36.295 \\
37.073 \\
37.587 \\
37.764\end{array}$ & $\begin{array}{l}0.08 \\
0.94 \\
0.55 \\
0.34\end{array}$ & $\begin{array}{l}\mathrm{C}_{11} \mathrm{H}_{16} \\
\mathrm{C}_{4} \mathrm{H}_{5} \mathrm{~N}_{3} \\
\mathrm{C}_{8} \mathrm{H}_{8} \mathrm{O}\end{array}$ \\
\hline 24 & $\begin{array}{l}\text { 1,3,5,7-tetraethyl-1-ethylbutoxysiloxy } \\
\text { cyclotetrasiloxane }\end{array}$ & 38.799 & 0.04 & \\
\hline 25 & $\begin{array}{l}\text { 1,5,9,9-tetramethyl-1,4,7,- } \\
\text { cycloundecatriene }\end{array}$ & 39.105 & 1.16 & $\mathrm{C}_{15} \mathrm{H}_{24}$ \\
\hline 26 & $\begin{array}{l}\text { 2-isopropyl-5-methyl-9-methylene- } \\
\text { bicyclo[4.4.0]dec-1-ene }\end{array}$ & 41.652 & 0.32 & $\mathrm{C}_{15} \mathrm{H}_{24}$ \\
\hline 27 & unidentified & 42.547 & 0.51 & \\
\hline 28 & d-cadinene & 44.629 & 0.04 & $\mathrm{C}_{15} \mathrm{H}_{24}$ \\
\hline 29 & perillaldehyde & 46.35 & 0.13 & $\mathrm{C}_{10} \mathrm{H}_{14} \mathrm{O}$ \\
\hline 30 & $\begin{array}{l}\text { 6,7,8,9-tetrahydro-6-methyl- } \\
4 \mathrm{H} \text {-pyrido[1,2-a]pyrimidin-4-one }\end{array}$ & 46.925 & 0.13 & $\mathrm{C}_{9} \mathrm{H}_{12} \mathrm{~N}_{2} \mathrm{O}$ \\
\hline 31 & 1-cyanoacetyl-3,5-dimethylpyrazole & 51.063 & 1.93 & $\mathrm{C}_{8} \mathrm{H}_{9} \mathrm{~N}_{3} \mathrm{O}$ \\
\hline 32 & 3-(4-methylpent-3-enyl)thiophene & 55.255 & 0.52 & \\
\hline 33 & caryophyllene oxide & 56.147 & 0.82 & $\mathrm{C}_{15} \mathrm{H}_{24} \mathrm{O}$ \\
\hline 34 & cis-decalin & 58.426 & 0.33 & $\mathrm{C}_{10} \mathrm{H}_{18}$ \\
\hline 35 & 1,4-dihydroxy-p-menth-2-ene & 60.382 & 0.13 & $\mathrm{C}_{10} \mathrm{H}_{18} \mathrm{O}_{2}$ \\
\hline 36 & espatulenol & 61.555 & 0.16 & $\mathrm{C}_{15} \mathrm{H}_{24} \mathrm{O}$ \\
\hline 37 & 2-ethyl-1H-imidazole & 63.991 & 29.80 & $\mathrm{C}_{5} \mathrm{H}_{8} \mathrm{~N}_{2}$ \\
\hline 38 & $\begin{array}{l}\text { 1-(1,1-dimethylethyl)- } \\
\text { 2-methylene-cyclopropane }\end{array}$ & 66.765 & 0.23 & \\
\hline 39 & unidentified & 71.351 & 0.10 & \\
\hline 40 & propanediamide & 73.612 & 0.22 & $\mathrm{C}_{3} \mathrm{H}_{6} \mathrm{~N}_{2} \mathrm{O}_{2}$ \\
\hline
\end{tabular}

In this study it is the first time to study the antitumor effect of the essential oil from $E$. dense in Sichuan Province, although the essential oil of many plants has been reported to be anti-tumor [7-13]. The essential oil from $E$. dense had a significant inhibitory effect on the proliferation of L02, SMMC-7721 and HeLa cells in a concentration dependent manner. The $\mathrm{IC}_{50}$ values show that SMMC-7721 cells were the most sensitive cells to the inhibitory effect of the essential oil. The inhibitory effect on proliferation of SMMC-7721 cells was time-dependent, however the inhibitory effect on proliferation of L02 and HeLa cells was alleviated when extending its treatment time from 8 hours to 24 hours. For 24 hour treatment with the essential oil, the effect was alleviated possibly because stress cell signaling in L02 and HeLa cells was stimulated and responded during this period. These results reveal that the essential oil from $E$. dense is cytotoxic, exerting stronger inhibitory effect on human hepatoma cells than normal liver cells. Therefore, it has great potential for development as an anti-liver cancer drug. 

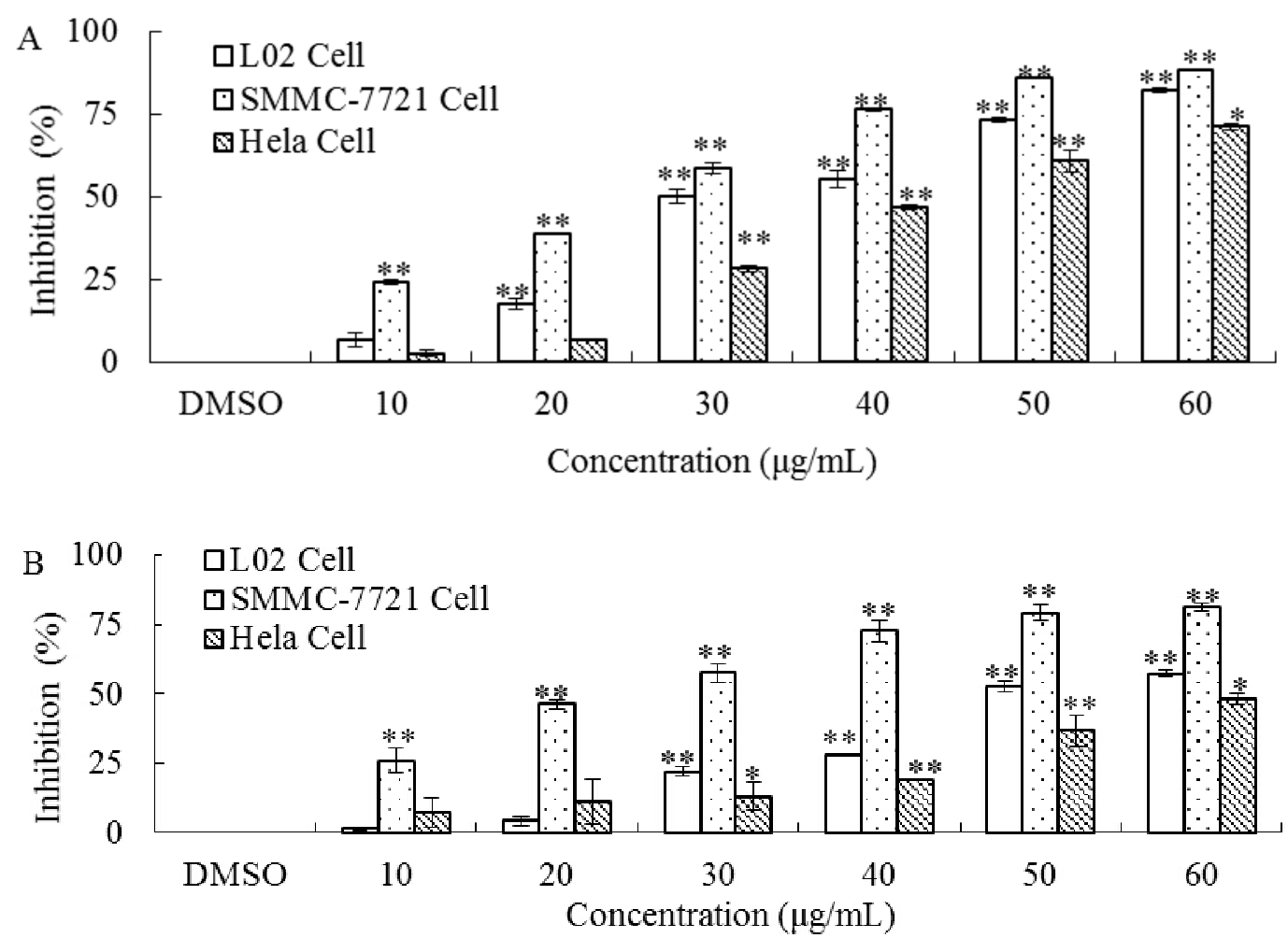

Figure 2: Inhibitory effects of the essential oil from E. dense on proliferation of L02, SMMC-7721 and HeLa cells. (A): 8 hour treatment with the essential oil; (B): 24 hour treatment with the essential oil. DMSO: cells were treated with $1 \%$ DMSO; ${ }^{*} p<0.05$ relative to DMSO treated cells, ${ }^{* *} p<0.01$ relative to DMSO treated cells

\section{CONCLUSION}

The yield of the essential oil from $E$. dense increased to $0.36 \%$ with the use of the modified steam-distillation extraction method. The main chemical components of the essential oil from $E$. dense are rosefuran epoxide, 2-ethyl imidazole, durenol, p-cymene, and 1-cyanoacetyl-3,5dimethylpyrazole. The essential oil of $E$. dense is cytotoxic, exerting stronger inhibitory effect on human hepatoma cells than normal liver cells. Therefore, the essential oil has great potential for development as an anti-liver cancer drug. Further studies are required to identify the active components responsible for its anti-tumor activity.

\section{DECLARATIONS}

\section{Acknowledgement}

This work was financially supported by key inoculation project of Sichuan Provincial Education Office (no. 16cz0005) and Openended Project of Key Laboratories in Universities in Sichuan Province (no. 201409).

\section{Conflict of Interest}

No conflict of interest associated with this work.

\section{Contribution of Authors}

The authors declare that this work was done by the authors named in this article and all liabilities pertaining to claims relating to the content of this article will be borne by them.

\section{Open Access}

This is an Open Access article that uses a funding model which does not charge readers or their institutions for access and distributed under the terms of the Creative Commons Attribution License (http://creativecommons.org/licenses/by 14.0) and the Budapest Open Access Initiative (http://www.budapestopenaccessinitiative.org/rea d), which permit unrestricted use, distribution, and reproduction in any medium, provided the original work is properly credited.

\section{REFERENCES}

1. Chinese Herbalism Editorial Board of State Administration of Traditional Chinese Medicine of the People's Republic of China. Chinese material medication- Tibetan Medicine. Shanghai: Shanghai Sci Tech Pub 2002; 48-49.

2. Luo SD. New Beads Medicinal Plants. Chengdu: Sichuan Sci Tech Pub 2004; 540. 
3. Sun $L P$, Yin $Z D, F u Z S$, Zheng $S Z$, Shen $X W$. The chemical constituents of Elsholtzia dense benth. Acta Bot Sin 1996; 38(8) : 672-676.

4. Zhang J, Wang ZH, Yao J, Huang AL, Gu LP, Wang J, Guo XL. The analysis of the essential oil of Elsholtzia dense benth. components. Acta Pratacult Sin 2005; 14 ( 1): $112-116$.

5. Wang Q, Zhao LJ, Han JM, Yang LL. Studies on the chemical constituents of the Elsholtzia dense benth. Chin Wild Plant Resour 1996; 2: 35-36.

6. Bao JY, Li JQ, Xiao YS. Analysis of volatile components of Elsholtzia dense grown in Qinghai Province. Food Sci 2014; 35(2): 231-237.

7. Liu WJ, Zhang DS, Chen WH, Chen GY. Composition and anti-tumor activities of essential oil of leaves of Xanthium sibiricum. Nat Prod Res Dev 2013; 25: 16801684.

8. $L i X B$, Chen $G Y$, Song $X P$, Han $C R$, Zheng $C J$. Composition and anti-tumor activities of essential oil from the fruits of dasymaschalon trichophorum. $J$ Chin Med Mater 2013; 30(33): 1786-1788.

9. Huang $G H$, Zhang DS, Song XM, Sun LJ, Song HW, $L i$ $Y X$, Zhang QY, Zhou J. Chemical components, cytotoxic and anti-microbial activity of essential oil of leaves of Poncirus trifoliate. Chin J Exp Tradit Med Form 2014; 20(5): 97-101.

10. Song $X M$, Liu $D X$, Song HW, Yang LJ. Chemical constituents of essential oil from Keteleeria Hainanensis. Guangdong Chem Ind 2015; 42(5): 21-22.
11. Xing $N$, Shu $Z P, X u B Q$, Jiao WJ, Li $Z Y$, Wang $Q H$, Kuang HX. GC - MS analysis of volatile oil components of Fructus Aurantiifrom in different regions and study of its anti-tumor activity. Inform Tradit Chin Med 2015; 32(5): 1-6.

12. Cheng WZ, Ma YF, Shao LX, Zhao TJ, Zhang JP, Xu LL, $L v X W$. The effects of essential oil from fingered citron leaves on morphology and structure of HeLa cells in vitro. J Zhejiang Norm Uni (Nat Sci) 2013; 36(3): 331336.

13. Wang YN, Zhu XH, Ma H, Du RY, Li DR, Ma DW. Essential oil of chenopodium ambrosioides induces caspase-dependent apoptosis in SMMC-7721Cells. J Chin Med Mater 2016; 5: 1124-1128

14. Liu AL, Lee SMY, Wang YT, Du GH. Elsholtzia: review of traditional uses, chemistry and pharmacology. J Chin Pharm Sci 2007; 16: 73-78.

15. Wollenweber E, Roitman JN. New reports on surface flavonoids from Chamaebatiaria (Rosaceae), Dodonaea (Sapindaceae), Elsholtzia (Lamiaceae), and Silphium (Asteraceae). Nat Prod Commun 2007; 2: 385-389.

16. Zhang J, Wang ZH, Yao J, et al. Analysis of volatile components of Elsholtzia feddei. J Lanzhou Uni (Nat Sci) 2004; 40(5): 69-72.

17. Fu LZ, LiHZ, LiRT. Constituent analysis of two Elsholtzia volatile oils. J Kunming Uni Sci Tech (Sci Tech) 2010; 35(1): 88-92. 